\title{
VERTAILEVAN MUSIIKKITIETEEN ALKUVAIHEITA EUROOPASSA
}

\section{Valokeilassa E. M. von Hornbostel ja A. O. Väisänen}

\section{Tausta}

1900-luvun alussa Keski-Euroopassa syntyi vertailevan musiikkitieteen nimellä tunnettu tutkimussuuntaus, jonka edustajat pyrkivät tutkimaan maapallon kaikkien alueiden musiikkeja. Sodan jälkeen 1950-luvulla sen rinnalle asettui Yhdysvalloissa kehittynyt etnomusikologia eli musiikkiantropologia, jonka edustajat vierastivat eurooppalaisten vertailevaa ja historiakeskeistä tutkimusta ja sen sijaan keskittyivät yksittäisten väestöjen musiikkien ymmärtämiseen opiskelemalla ne ensin itse. Poikkeuksena tästä suuntauksesta oli Alan Lomaxin globaali analyysi laulun esitystyyleistä (Lomax 1968; Lomax \& Arensberg 1977).

Etnomusikologitkin kyllä vertailivat mutta etupäässä tutkimuskohteittensa musiikkitulkintoja omiin läntisiin musiikkinäkemyksiinsä, minkä seurauksena he ajautuivat vastatusten länsimaista taidemusiikkia tutkineiden musiikkitieteilijöiden kanssa. Vertaileva musiikkitiede on säilynyt musiikkitieteen muunnoksena Euroopassa, mutta sen kohteena on edelleen luovan työn tuote, ei niinkään sen tausta. 
Vertailevan musiikkitieteen synty liittyy laajempiin 180o-luvun lopun teknologian ja tieteen kehityksiin. Yhdysvaltalainen Thomas Edison keksi vuonna 1877 keinon siirtää ja tallentaa ääntä pyörivälle vahalieriölle (Gronow ja Saunio 1990: 30-31). Kielen- ja musiikintutkijat ottivat fonografina tunnetun tallennus- ja toistolaitteen käyttöönsä jo 189o-luvulla Yhdysvalloissa ja Euroopassa. Toisen sysäyksen vertailevan musiikkitieteen syntyyn antoivat englantilaisen foneetikon Alexander Ellisin (Stock 2007) 188o-luvulla julkaisemat tutkimukset, joissa hän vertaili eri väestöjen ei-harmonisia sävelasteikkoja ja kehitti moninaisten intervallien vertailuun senttijärjestelmän, jossa tasavireinen puolisävelaskel jakautuu 100 senttiin ja oktaavi 1200 senttiin. Saksankielisen alueen tutkijat tajusivat musiikintutkimuksen olevan muuttumassa kuvailusta eksaktiksi tieteeksi. Kolmantena käynnistäjänä oli monitieteisellä saksankielisellä tutkimustyöllä kehkeytynyt diffuusio- eli kulttuuripiiriteoria (Kulturkreislehre), joka oli keskittynyt globaaliin vertailuun (Berner ym. 2015). Teorian mukaan innovaatiot olivat levittäytyneet (diffusoituneet) alueelta toiselle rengaslaineiden tapaan. Kun tutkijat yhdistivät nämä kolme osatekijää, vertaileva musiikkitiede muotoutui nopeasti musiikkitieteen uudeksi suuntaukseksi.

Tuossa tilanteessa aivan keskeiseksi henkilöksi nousi Erich Moritz von Hornbostel (1877-1935), joka oli mukana melkein kaikessa, mihin tämä uusi tutkimussuuntaus kohdisti huomion. Hän on kuitenkin pysynyt salaperäisenä hahmona musiikkitieteen historiassa. Vuosikymmenet olen kysynyt: Mistä hän tuli, kuka hän oli ja minne katosi? Mikä oli se Berliinin koulukunta, jota hän johti yhdessä Carl Stumpfin kanssa, ja miksi Curt Sachs (1881-1959) laajoine tuotantoineen nousi 1940-luvulta alkaen vertailevan musiikkitieteen kuten myös nuoren etnomusikologian kärkinimeksi? Hornbostel haihtui kuin usva tuuleen, ja hänet muistetaan enää vain soitinten luokitusjärjestelmän tekijänä ja ylipuhaltuville kvinteille rakentuvan epäonnisen asteikkoteorian luojana. Edelleen: mitä diffusionismi perimmältään tarkoitti ja miten siihen suhtauduttiin Suomessa, jolla oli likeinen yhteys Saksaan? Suomessa toimi 1900-luvun ensipuoliskolla merkittäviä kansanmusiikin tutkijoita, kuten Otto Andersson (1879-1969, Nyqvist 2007) ja Armas Otto Väisänen (1890-1969), mutta tämän artikkelin puitteissa tyydyn suomalaistutkijoista miettimään vain jälkimmäisen suhdetta vertailevaan musiikkitieteeseen. Miksi ylipäätään peilaan Hornbostelia suomalaiseen musiikintutkimukseen, johtuu halusta tietää, löytyykö tuolta ajalta tutkijoita, jotka olivat 
ehdoitta joko diffusionisteja tai evolutionisteja. Ensin on syytä luonnehtia kumpaakin suuntausta 1900-luvun alun keskieurooppalaisessa tutkimuksessa.

\section{Darvinistinen evoluutioteoria vs. diffusionistinen kulttuuripiiriteoria}

Eurooppalaiset ajattelijat kiinnostuivat 180o-luvulla etsimään moninaisille tutkimuskysymyksille selityksiä sekä rationaalisesti että globaalisti. Kuuluisimpia heistä oli luontoa tutkinut Charles Darwin (Ferrington 1971), joka viiden vuoden aikana kiersi maapallon ja päätyi empiiristä tietä pohtimaan erilaistumisen syitä: miksi sama esiintyy niin monina muunnoksina? Hänen selityksensä siihen oli olemassaolostaan taistelevien osapuolten tekemät valinnat. Empiiristen havaintojen tulkinta johti evoluutioteoriaan, jonka mukaan muuttuvan ympäristön paine pakottaa aina muutoksiin ja näin olemassa olevista kehittyy uusia muunnoksia ja erilaistuminen on jatkuvaa. Toisaalta luonnonvalinta saattaa aiheuttaa sen, että samankaltaiset ympäristöolosuhteet pakottavat yhdenmukaisiin ratkaisuihin eri puolilla maapalloa. Erilaistumisen pakko saattaa siis johtaa eri lajien samanlaistumiseen, mitä kutsutaan rinnakkaiskehitykseksi. Yhtenä esimerkkinä tästä kaksi kalastajaa on saattanut kehittää samanlaisen koskipyydyksen kahdella mantereella toisistaan tietämättä.

Monet muutkin eurooppalaiset liikkuivat eri puolilla maapalloa ja keräsivät laaja-alaisia tutkimusaineistoja muun muassa arkeologian, etnografian, kielen ja folkloren alalta, mutta heidän keskuudessaan alkoi nousta esiin tarve pohtia eri alueilta löytyneiden samankaltaisuuksien syitä. Saksalainen Friedrich Ratzel (k. 1905) oli maantieteilijä, jonka globaali vertailutyö johti "kulttuurihistorialliseen menetelmään". Siinä tulkinnan kriteereitä olivat (a) ulkoisen muodon ja materiaalin samuus sekä (b) samuuksien määrä (Smith 1980). Hänen seuraajansa oli afrikanisti Leo Frobenius (k. 1938), joka otti käyttöön termin kulttuuripiiri vuonna 1897 ja joka muun muassa havaitsi, että afrikkalainen ksylofoni oli indonesialaisen muuttoaallon jälki (Frobenius 1898). Kulttuuripiiri tarkoitti kartalle piirrettyä ympyrää, kehää, jonka sisässä oli yhtäläinen kulttuuri ja keskipisteessä alkukulttuuri. Tutkimuksen päämäärä oli määrittää maapallon kulttuuripiirit, joita oli muodostunut ihmisen vaellettua alati kauemmas alkukulttuurista. Jotkut tutkijat sijoittivat tämän alkukulttuurin Egyptiin. 


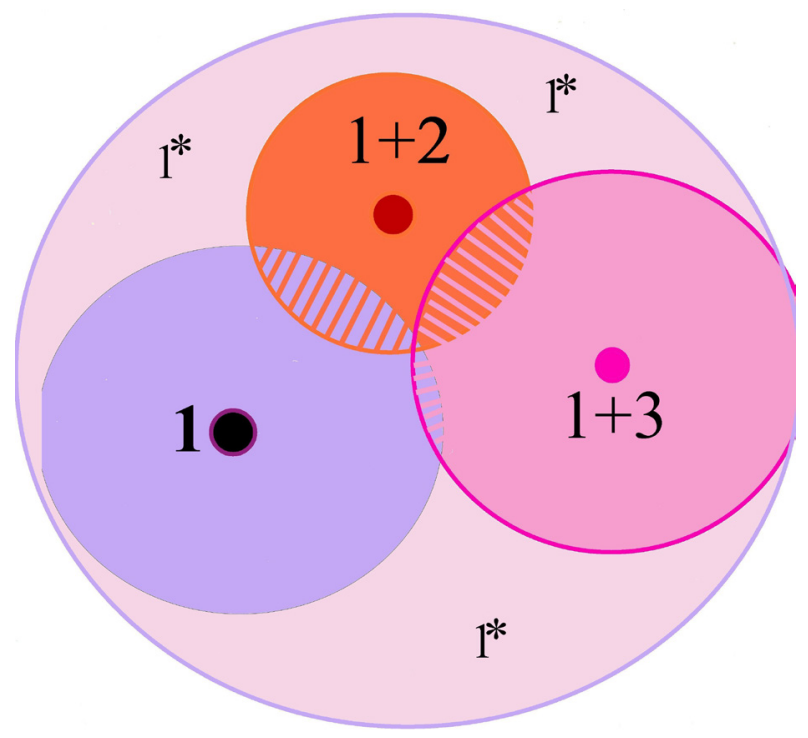

Kuva 1. Kolme hypoteettista kulttuuripiiriä 1, 2 ja 3. Alkukulttuurin (1) aineksia säilyi siitä irtautuneissa uusissa kulttuuripiireissä $1+2$ ja $1+3$. Kukin piiri laajeni väestön levitessä eri suuntiin ja kuljettaessa kulttuurin vanhoja ja uusia elementtejä mukanaan. Ihmisen otettua haltuunsa kaikki asuttavat mantereet vanhimman kulttuuripiirin (1) häivähtyneet jäänteet ( $1^{*}$ : iso ympyrä) pitivät sisällään koko maapallon.

Tähän teoriaan tarttui katolinen pappi ja Wienin yliopistossa toiminut etnologi Wilhelm Schmidt (1868-1954). Hän muotoili 190o-luvun alkuvuosikymmeninä kulttuuripiirien teorian sopivaksi globaaliin tutkimukseen, ja näin muotoutui Wienin koulukunta. Isä Schmidt siis kehitti tieteelliseksi muotoillun teorian, joka pyrki todistamaan Raamatun luomiskertomuksen todeksi ja horjutti Darwinin evolutionistisia väitteitä. Kulttuuripiiriteorian "alkukoti" oli Vanhan testamentin Paratiisi (kuva 1:1), ja rengaslaineen tapaan sieltä muuttaneiden mukana kulttuurien ainekset levittäytyivät kaikkialle. Näin "piirit" alkoivat muotoutua heti syntiinlankeemuksen jälkeen. Schmidt itse pyrki osoittamaan universaalilla aineistolla, että ihmisen alkukotia oli hallinnut monoteismi. (Schneider 1976.)

Vertailevan musiikintutkimuksen edustajat Berliinissä innostuivat kulttuuripiiriteoriasta. Mielenkiintoista kyllä he eivät tiettävästi olleet tietoisia evolutionismista kauhistuneen Schmidtin kristillisistä motiiveista, ehkä sen vuoksi, 


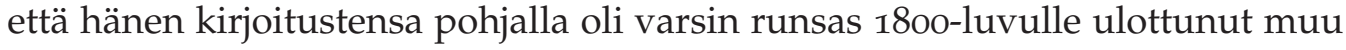
tutkimus. Kiistanalaisesta taustasta huolimatta kulttuuripiiriteorian ydintä ei ole syytä väheksyä, sillä se on pysynyt tieteellisesti validina. Vaikka yhdestä keskipisteestä ympyrämäisesti levinneitä ja globaaleja mittasuhteita saavuttaneita kulttuuriekspansioita ei todellisuudessa liene ollut koskaan olemassa, niin rengaslaineen tapaan edenneitä paikallisia "piirejä" on esiintynyt eri puolella maailmaa kautta aikojen (kuten Suomi-rock Tampereen ympäristössä ja Nigerian ympäristön jùjú [Waterman 1990]).

Keskeistä mielestäni on kuitenkin se, että koska kirjoituksettomien kulttuureiden historiaa selvitelleiden tutkijoiden käytössä olleita todisteita oli niukanlaisesti tai ei ensinkään, vertailevan musiikkitieteen pioneerit turvautuivat kolmeen aksiooman, joita kukaan ei tieteenhistoriassa ole vielä katsonut tarpeelliseksi todistaa vääriksi: (1) Soitin, joka on olemassa tietyllä rajatulla alueella jossain maapallon kolkassa, on vanhempi kuin sellainen soitin, joka löytyy kaikkialta. (2) Syrjäisillä vuorilla ja saarilla laajalti käytetty soitin on vanhempi kuin sellainen, jota käytetään tiheästi asutuilla seuduilla. (3) Soitin on alkuperältään sitä varhaisempi, mitä hajanaisemmin ja mitä laajemmalle alueelle se on maapallolla levinnyt. Väitteet kiinnittyvät 190o-luvun alun tilanteeseen ja ovat tietenkin vanhentuneita, jos tutkimuskohteena on vaikkapa syntetisaattorin tai sähkökitaran kaltaisen modernin soittimen leviäminen, mutta ilman näitä väitteitä meillä ei olisi soitinten maailmanhistoriasta sitä selkeähköä yleiskuvaa, joka meillä nykyisin on.

Toisin kuin Keski-Euroopassa evoluutioteoria ja kulttuuripiiriteoria eivät Suomessa ajautuneet vastatusten, koska isä Schmidtin ideologinen valta ei ulottunut Euroopan pohjoisimpiin osiin. 180o-luvun puolivälistä alkaen suomalaiset kuitenkin seurasivat tarkkaan tieteen ajankohtaisia virtauksia. Maassa syntyi uusia tieteenaloja, ja yhdet löysivät ongelmiinsa ratkaisut evoluutioteoriasta, toiset diffuusioteoriasta. Vielä 1970-luvulla professori uskalsi rohkaista opiskelijaa sanomalla "kyllä työ tekijäänsä neuvoo", eli tämän evästyksen mukaan tutkimusaineisto ja tutkimustehtävä opastivat soveliaimpaan teoriaan. Perimmältään evolutionismin ja diffusionismin välisen kiistan ydin näyttäisi Keski-Euroopassa olleen luomiskertomuksen synnyttämä metateoria ja sen puolustaminen. Suomalaisia tuo kiista ei rasittanut, vaan nuo kaksi teoriaa elivät rinta rinnan. 
Täysin kitkatta ei Suomessakaan kyetty tietoa tuottamaan, sillä tutkijoihin vaikutti evoluutio- ja diffuusioteorioiden lisäksi voimakas metateoria itämerensuomalaisten, suomalais-ugrilaisten ja samojedien kulttuureja yhdistäneestä uralilaisesta kantakulttuurista. Arkeologian ja etnografian alkuunpanijaa, Axel Heikeliä, tutkinut Timo Niiranen (1987) on valottanut sitä, miten suomalaisten humanististen tieteiden alkuvaiheissa eri alojen tutkijoille näyttäisi olleen oleellisinta kehittää keinoja saavuttaa tuota metateoriaa tukevia tutkimustuloksia. Esineiden, tapojen, yhteisörakenteiden ja laulutekstien tutkijat alkoivat vertailemalla muodostaa kehityssarjoja luonnontieteellisen darvinismin tapaan. Ongelmana pysyi kuitenkin aina sama: johtuuko samankaltaisuus rinnakkaiskehityksestä vai lainasta? Tiedot kirjoitustaidon synnystä tarjoaa esimerkin. Vielä 1940-luvulla assyriologit päättelivät Mesopotamian sumerien alkaneen siirtää ajatusta kirjoitukseksi noin 5100 vuotta sitten, mutta tutkijat olivat epävarmoja siitä, käynnistyikö sama Egyptissä itsenäisesti vai lainattuna Sumerista (Salonen 1945). Nykytietämys vahvistaa tosiasiaksi, että kirjoitustaito syntyi Sumerissa noin 5500 vuotta sitten ja lainautui Egyptiin diffuusion seurauksena vasta useita sukupolvia myöhemmin.

Suomensuomalaisten ja suomenruotsalaisten musiikinhistorian tietoteoreettista analyysiä ei ole tyhjentävästi kirjoitettu. (Ks. kuitenkin Kurkela 2011; Mantere 2017; Pekkilä 1982 ja 1988; Piela ym. 2011.) On ilmeistä, ettei sellaista voida kirjoittaa tuntematta muiden humanististen tieteiden lähtökohtia. Muun muassa etnologian, arkeologian ja folkloristiikan alan akateemisten opettajien ja opiskelijoiden määrä oli suurempi kuin musiikin alalla, ja voidaan väittää, että näiden alojen johtavilla tutkijoilla oli mahdollisuus miettiä monia muita humanistisen alan tutkijoita perusteellisemmin työnsä pohjalla olleita tietoteoreettisia rakenteita. Kustaa Vilkunan (1961) pitkäaikaisen teoretisoinnin keskeiset ainekset ja lähteet näkyvät hänen artikkelissaan "Onko erityistä suomalais-ugrilaista kansatiedettä?" Musiikin harvat tutkijat pyrkivät seuraamaan Vilkunan luettelemia ajatuksia ja käyttivät niistä johdettuja menetelmiä, mutta eivät itse alkaneet liiemmin teoretisoida. 


\section{Erich M. von Hornbostel}

Itävaltalainen Erich Moritz von Hornbostel oli vanhaan alasaksilaiseen sukuun kuuluneen asianajaja Erich Otto von Hornbostelin ja wieniläisen laulajatar Helen(e) Magnusin poika (Goodman 2016). Erichin äidinisä oli wieniläinen kuten myös hänen isänisänsä, teollisuusneuvos ja pankkiiri Theodor Friedrich Hornbostel. Theodor oli saavutustensa vuoksi aateloitu vuonna 1860, joten hänen jälkeläisillään oli oikeus käyttää sukunimensä edellä liitettä von. Äiti, kamarilaulaja Helen Magnus, kuului Euroopan monissa maissa vaikuttaneeseen juutalaiseen Magnus-sukuun, ja kerrotaan (Goodman 2015) säveltäjä Johannes Brahmsin ihailleen hänen ääntään.

Erich von Hornbostel väitteli Wienin yliopistossa pääaineenaan kemia vuonna 1900. Samalla hän oli opiskellut sointuanalyysiä ja sävellystä. Hän innostui Carl Stumpfin (1848-1936) tutkimuksista, muutti Berliiniin ja alkoi opiskella tämän johdolla kokeellista psykologiaa ja musiikkitiedettä. Stumpfin rinnalla musiikkitiedettä oli kehittämässä myös saksalainen lääkäri ja laitoksessa apulaisprofessorina vuoteen 1905 työskennellyt Otto Abraham (1872-1926), joka oli muun muassa musiikin fysiologian ja psykoakustisen tutkimusalan pioneeri (Wachsmann ym. 1975). Erich toimi Stumpfin alaisuudessa psykologian assistenttina yhden vuoden ja oli aivan ilmeisesti opettajansa suosikki. Carl Stumpf oli vertailevan musiikkitieteen pääideologi, jolla oli sittemmin syvällinen vaikutus Pohjois-Amerikan etnomusikologiaan. Vuonna 1911 hän julkaisi musiikin syntyä käsittelevän kirjansa Die Anfänge der Musik. Stumpf oli erityisen kiinnostunut musiikin ja mielen suhteista ja oli näin nostamassa musiikkipsykologiaa omaksi oppialakseen ja osaksi empiiristä tutkimusta. Hän pyrki selittämään, miten muun muassa havaitseminen ja ymmärtäminen tapahtuvat aivoissa (Stumpf 1892) ja mikä on konsonanssi- ja dissonanssikokemuksen selitys (Stumpf 1911b). (Lisätietoja Carl Stumpf -seuran kotisivulta http:/ /www.carl-stumpf.de/.)

Professori Stumpf ja hänen assistenttinsa von Hornbostel perustivat vuonna 1900 yliopiston psykologian laitokseen äänitearkiston, joka pian itsenäistyi ja sai nimekseen Das Berliner Phonogrammarchiv (Koch ym. 2004; Simon 2000). Vuonna 1906 sen johtajaksi nousi von Hornbostel, jonka ensimmäisiä toimia oli vierailla Chicagossa ja työskennellä Georg A. Dorseyn kanssa Oklahoman pawnee-intiaanien parissa. Palattuaan hän nuotinsi joukon äänitteitä ja teki analyysin 
pawneiden musiikista, mutta työ jäi julkaisematta (Parks 1997: xvi-xvii). 1900-luvun alkuvuodet Hornbostel toteutti pioneeriurakan: koska arkisto oli alkanut saada eri puolilta maailmaa joukoittain fonografilla tallennettuja äänitteitä, "fonogrammeja", hän alkoi transkriboida ja analysoida niitä. Prosessi oli jotain aivan uutta maailmassa. Hänellä oli nuotintaessaan aina mielessä psykologinen kysymys: miten melodioissa näkyvät laulajien mielensisällöt. Tutkija julkaisikin koko joukon tähän liittyneitä analyysejä, joista varhaisimmat on myöhemmin julkaistu uudestaan englanninkielisine käännöksineen (Wachsmann ym. 1975).

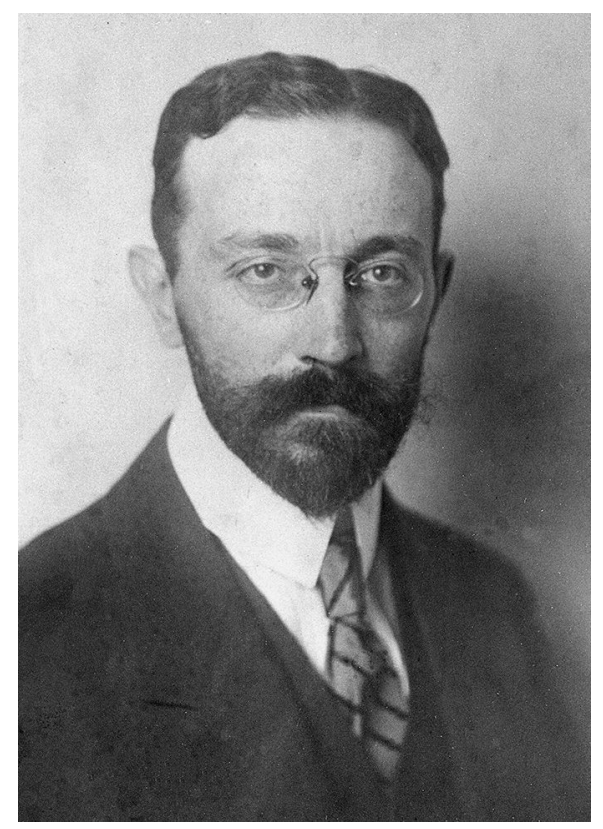

Kuva 2. Erich von Hornbostel 1930-luvun alussa otetussa passikuvassa. Kuva: mundoselknam. wordpress.com.

Hornbostelin monipuolisuutta osoittaa hänen laaja arvostelunsa Hans Heldin vuonna 1905 julkaistusta tutkimuksesta, joka koski Cortin elimen toimintaa nisäkkäiden sisäkorvan simpukassa (Wachsmann ym. 1975: 287-290). Hornbostel oli miettinyt yllättävän analyyttisesti, miten tuo neljästä hiussolujonosta koostuva rakenne liittyy nisäkkäiden kykyyn kuulla ääniä. Mikä sai hänet kiinnostumaan juuri tuosta pikkuriikkisestä elimestä tehtyyn tutkimukseen, jää salaan. 
Hämmästyttävää kyllä yli sata vuotta myöhemmin alkoi valjeta, että juuri Cortin elin on se ensimmäinen elin, joka muuntaa akustisen värähtelyn neuronaalisiksi koodeiksi samaan tapaan niin kissoilla ja pyöriäisillä kuin ihmisillä, ja lopulta kuuloaivokuoren solujen purkauksista muodostuu periodotopia eli "kartta", jonka kuulija kokee sävelkorkeuksina (Langner 2015: 61-87).

Hornbostelin musiikkianalyyttisistä tutkielmista näkyy, että hän pyrki haarukoimaan aineistoja, jotka jakautuivat kohtalaisen tasaisesti eri puolille maapalloa. Eurooppa häntä ei kiinnostanut. Hän oli varsin likeisesti tekemisissä opettajansa Stumpfin kanssa tämän valmistellessa teostaan Die Anfänge der Musik, ja on todennäköistä, että juuri Hornbostel etsi, valikoi ja nuotinsi teoksen runsaan sävelmäaineiston. Kirjan toisella aukeamalla lukeekin, että teos on "ystävyydellä omistettu" Hornbostelille: "Herrn Dr. Erich M. von Hornbostel, dem Leiter des Berliner Phonogramm-Archivs, in Freundschaft zugeeignet" (Stumpf 1911a).

Vuonna 1904 Berliinissä oli syntynyt kansainvälinen levy-yhtiö Carl Lindström AG, joka äänitti eri puolilla maailmaa paikallisia muusikoita ja tuotti voittoa myymällä samoja äänitteitä muusikkojen omilla elinalueilla. Hornbostel oli ensimmäinen tutkija, joka tajusi, että kaupalliset levy-yhtiöt tekivät merkittävää musiikkiantropologista dokumentointityötä, joten hän keräsi ja arkistoi näitä levyjä tutkimuskäyttöön. Carl Lindström AG oli äänittänyt Aasiassa ja PohjoisAfrikassa sikäläisille markkinoille suunnattua musiikkia, mutta Hornbostel sopi, että yhtiö julkaisee valikoiman näitä äänitteitä myös lännessä. Vuonna 1931 ilmestyi kahdentoista kaksipuolisen levyn kansiona Musik des Orient, jonka mukana oli Hornbostelin esittelyteksti. Juridisista syistä kokoelma ilmestyi Saksassa sekä Parlophon- että Odeon-levymerkillä. Englannissa julkaisun levymerkkinä oli Parlophone ja Yhdysvalloissa Decca. (Gronow \& Hofer 2009-2010).

Berliinissä syntynyt Curt Sachs (1881-1959) väitteli 1904 tohtoriksi taidehistorian alalla, mutta hän päätti sitten siirtyä tuolloin kokolailla vielä olemattoman musiikkitieteen piiriin, koska kuvataiteen lisäksi häntä kiinnosti musiikki. Niinpä hän hakeutui Berliinin yliopiston psykologian laitokselle eli Carl Stumpfin suojiin. Sachs oli Hornbostelia neljä vuotta nuorempi ja ensi alkuun hieman sivullinen, koska Stumpf ja Hornbostel muodostivat matemaattis-psykologisen tutkimustiimin. Tästä huolimatta nämä Stumpfin nuoret opiskelijat onnistuivat lyöttäytymään yhteen ja luomaan teoksessa Systematik der Musikinstrumente (1914) soitinten luokitusta koskevan globaalin järjestelmän (1914), jota ei nähdäk- 
seni ole vieläkään kyetty korvaamaan paremmalla. Pari toimi erinomaisesti, koska Hornbostel kykeni matemaatikkona luomaan toimivan luokitusjärjestelmän ja Sachsilla oli ilmiömäinen kyky hahmottaa nopeasti soitinten ominaisimmat rakennepiirteet ja hallita kansainvälinen, soitinkuvituksia sisältävä kirjallisuus.

Hornbostel oli ennen kaikkea kiinnostunut sävelmien rakenteista ja musiikin vaikutuksista psyykeen, mutta hän oli myös utelias ymmärtämään, miten eri alueiden soittimet suhteutuvat historiallisesti toisiinsa. Hyvä esimerkki tästä on kaksi vuonna 1933 ilmestynyttä artikkelia, joissa hän määritti Afrikan maanosan eri soitinlajien maantieteelliset ja historialliset koordinaatit. Alan Merriam arvosti Hornbostelia tämän psykologisten näkemystensä vuoksi, mutta mietiskellessään Hornbostelin ja Sachsin diffusionistisia päätelmiä soitinten keskinäisistä ikäsuhteista hän (1968: 287-290) totesi niihin sisältyvän epäuskottavuutta, koska todisteita oli niukalti. Tästä huolimatta hän tunnusti, että tutkijakaksikon soveltamat kolme diffusionistista ikäämiskriteeriä olivat edelleen valideja ja että niitä voidaan hyödyntää tutkittaessa kulttuuriainesten vaellusten historioita - jos kohta ei aivan siinä mitassa kuin kaksikko oli olettanut.

Hornbostel (1910: 143-167) oli jo varhain mietiskellyt empiirisen tutkimuksen tärkeyttä musiikkipsykologiassa, ja seuraavana vuonna hän kirjoitti Stumpfin kanssa artikkelin, jossa he pohtivat etnologisen (nykykielellä: kulttuuriantropologisen) näkökulman antia musiikin psykologiselle ja esteettiselle tutkimukselle (Stumpf \& Hornbostel 1911). Linjassa tämän kanssa hän kysyi, miksi ihmisellä on kaksi korvaa, ja vastasi: kuullakseen tilan. Hän järjesti neljättäkymmentä empiiristä koetta ymmärtääkseen, mitä tilan havainnointi oikein tarkoittaa. Kokeessaan no. 32 hän havaitsi, että sijoittamalla seinämä liikkumattoman äänilähteen eteen, ääni kuullostaa kaukaiselta, mutta jos seinämän siirtää lähteen taakse, ääni ikään kuin kuuluu likeltä. (Hornbostel 1923.) Tämän kaltaiset kokeet tuntuvat nykyopiskelijalta triviaaleilta, mutta reaktio on vahingollinen, koska se estää tajuamasta, miten valtavasti tietomme on lisääntynyt kaikilla alueilla viimeisen sadan vuoden aikana. Toisaalta se estää myös pysähtymästä ja tajuamasta, että tilan hahmottaminen kuulemalla oli ollut olemassaolon taistelun keskeinen väline jo kymmenet miljoonat vuodet - ja on edelleen esimerkiksi näkövammaisille. 


\section{Sammelbände für Vergleichende Musikwissenschaft

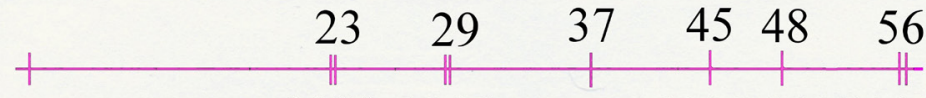 \\ $1877 \quad 190019061914192219251933$ \\ Dr. FonA H\&S $s_{\text {fir }} V M$ Prof $\varnothing$}

Kuva 3. Hornbostellin elämän taitekohtia. Ylinnä ovat ikävuodet, alla vuosiluvut: väitöskirja

(Dr.), Fonogrammiarkiston johtajuus (FonA), soitinluokitus (H\&S), Sammelbände-lehden toimitus, nimitys professoriksi ja holokausti käynnistyy (Ø).

Toisaalta Hornbostel (1913) liikkui aivan muilla urilla alettuaan miettiä soitinten viritysten merkitystä kulttuurien historialliselle tutkimukselle. Hän oli vuosia kestäneiden nuotinnosprosessien aikana oivaltanut, että kaukaistenkin väestöjen säveljärjestelmillä voi olla yhteys. Hornbostel ei tiennyt mikä yhteys, mutta hän kehitti hypoteesin, jonka mukaan itäisen Aasian, Tyynenmeren ja Etelä-Amerikan intiaanien säveljärjestelmillä on geneettinen kytkös. Perusteluna oli se, että näillä alueilla käytetään samankaltaisia huiluja, jotka viritetään ylipuhaltamalla eli kvintti- ja kvarttisarjoin (Hornbostel 1928). Toisin sanoen kun huilulla puhalletaan sävel ja sitten vahvemmalla puhalluksella syntyy sen ylempi kvinttisävel, saadaan aikaan sävelikkö, joka selittää mannertenväliset samankaltaisuudet huilujen virityksissä. Hornbostel julkaisi kirjoituksensa kehitysoppia ehdoitta vastustaneen Wilhelm Schmidtin 6o-vuotisjuhlakirjassa. Hornbostelin rakentamaa ylipuhaltuvien kvinttien teoriaa on sittemmin pidetty virheellisenä (muun muassa Kunst 1948), mutta aivojen kuulokeskusta tutkinut Gerald Langner $(2015,54-59)$ nosti Hornbostelin hypoteesin myöhemmin esille. Perusteena on se 0,4 millisekunnin aikavakio, jonka kuluessa sähköinen impulssi siirtyy hermosolusta seuraavaan. Kuulokeskuksen yhteensattumasolut etsivät harmonisessa aikasuhteessa toisiinsa olevia samanaikaisia impulsseja, ja jos samankaltaisuuksia on, kuulokeskus tunnistaa ne tuon vakion kerrannaisista $(2 \times 0,4,3 \times 0,4$, 4×0,4 ... ms). Koska vakio on kaikissa ihmisissä (itse asiassa kaikissa tasalämpöisissä) sama, se voisi johtaa myös kulttuureista riippumatta eri aikojen ja alueiden huilusoittimissa samankokoisiin intervalleihin, mikä tukee Hornbostelin hypoteesin universaaliluonnetta. Selitys ei siis johdu ylipuhaltuvista kvinteistä, vaan kuulokeskuksen aikavakiosta. Uutta tutkimusta edustavat edelleen Ebeling \& 
Langner 2016 ja Schwörer-Kohl 2016. Näin sekä alkuperäinen hypoteesi että sen tyrmäykset on tarjottu koeteltaviksi uudelleen.

\section{Hornbostel, juutalaisuus ja musiikintutkimus}

Palaan ajassa vertailevan musiikkitieteen alkuaikoihin. Kokeellisen psykologian keskeinen käynnistäjä, saksalainen Carl Stumpf, oli professorina Berliinissä 1893-1928. Sinne alkoi siirtyä nuoria tutkijoita, joita kiinnosti uudenlainen musiikintutkimus. Täten vertaileva musiikkitiede ja sen Berliinin koulukunta kehkeytyivät Friedrich-Wilhelms-yliopiston eli nykyisen Humboldtin yliopiston psykologian laitoksessa. Hornbostel oli väitellyt 1900, ja jo samana vuonna hän oli kokoamassa Berliinin fonogrammiarkistoa, joka hallinnollisesti syntyi 1904. Psykologian laitoksesta se irtaantui 1923, jolloin se siirtyi osaksi Berliinin musiikkikorkeakoulua. Koulukunnan varhaiselle tutkimukselle keskeinen lääkäri Otto Abraham kirjoitti lukuisia artikkeleita Hornbostelin kanssa tämän nuotintamien sävelmien pohjalta. Siis Stumpf, Hornbostel, Abraham ja Sachs käynnistivät Berliinin koulukunnan, joka edusti Wienin koulukunnan tapaan kulttuuripiiriteoriaa. Varsinkin Sachs sivuutti darvinistiset selitysvaihtoehdot, kun taas Stumpf ja von Hornbostel arvostivat myös Darwinin järkeilyjä. Uuden tieteenalan, vertailevan musiikkitieteen, viestimenä Hornbostel alkoi vuonna 1922 toimittaa Carl Stumpfin kanssa aikakauslehteä Sammelbände für vergleichende Musikwissenschaft. Vuonna 1925 hän sai nimityksen systemaattisen ja vertailevan musiikkitieteen professoriksi Berliiniin.

Aateloituun sukuun kuulunut Erich von Hornbostel oli maailman suurimman äänitearkiston johtaja ja Berliinin yliopiston professori. Adolf Hitler ryhtyi hallitsemaan valtakunnankanslerina Saksaa 1.4.1933. Heti valtaannousun jälkeen kansallissosialistien rynnäkköjoukot (sA) alkoivat irrottaa juutalaisia heidän oikeudellisista kytkennöistään yhteiskuntaan. 56-vuotias Hornbostel menetti hetkessä professuurinsa sekä asemansa perustamassaan Berliinin fonogrammiarkistossa. Hän järjesti pakomatkansa ensin Sveitsiin ja sieltä Ranskaan, josta hän vaimonsa Susannen ja poikansa John Hans Hornbostelin kanssa pakeni syyskuussa 1933 laivalla New Yorkiin (Goodman 2015; Ziegler n.d.). Elämänmuutos mursi tutkijan. Hornbostel yritti sopeutua New Yorkiin, mutta siirtyi seuraavana vuonna 
Lontooseen. Tarkoituksena oli aloittaa uusi elämä tuntiopettajana Cambridgen yliopistossa, mutta terveys petti ennen työn alkua marraskuun lopulla 1935. Leski ja poika palasivat Yhdysvaltoihin.

Natsien etsimistä intellektuelleista jotkut löysivät Lontoossa pakopaikan asuntokeskuksesta nimeltään Lawn Road Flats. Hornbostelit asuivat hetken sen huoneistossa nro. 6. David Burke (2014: 65-66) on kuvannut professorin kohtaloa teoksessaan The Lawn Road Flats toteamalla, että tämä oli yksi verisimmin raadelluista eurooppalaisista neroista, joita kansallissosialistit olivat tuhonneet puhdistaessaan saksalaista rotua.

Erich von Hornbostel ei ainoastaan ollut etevä tutkija vaan myös vaikutusvaltainen opettaja oppilainaan Saksan juutalainen Curt Sachs, Itävallan juutalainen Robert Lachmann (1892-1939, vertailevan musiikkitieteen Berliinin koulun perustajajäseniä ja Zeitschrift für vergleichende Musikwissenschaft -lehden päätoimittaja) sekä Unkarin juutalainen George Herzog (1901-1983, ks. Reed 1983). Herzog opetti muun muassa sittemmin etnomusikologisen tutkimuksen klassikkonimiin nousseita Alan P. Merriamia (1923-1980) ja Bruno Nettliä (s. 1930) Indianan yliopistossa. Muista Hornbostelin oppilaista Kanadaan paennut Puolan juutalainen Mieczyslaw Kolinski (1901-1981) toimi Toronton yliopiston luennoitsijana sekä musiikkiterapeuttina.

Kaikki Hornbostelin oppilaat eivät tietenkään olleet juutalaisia. Oli hollantilainen Jaap Kunst (1890-1961, etnomusikologia-sanan keksijä), saksalaiset Hans Hickmann (1908-1968), Marius Schneider (1903-1982) sekä Fritz Bose (19061975), joka jatkoi Hornbostelin työtä yli natsien kauden ja vieraili tallentamassa musiikkia Karjalassa. Erich von Hornbostelin opetusta oli Saksaan tullut hakemaan Yhdysvalloista myös säveltää ja teoreetikko Henry Cowell (1897-1965), joka oli sittemmin säveltäjä John Cagen (1912-1992) opettaja. Hitleristä ja natsien vainoista huolimatta Erich von Hornbostel vaikuttaa yhä musiikin tutkimukseen ja taiteeseen.

Voidaan kysyä, miksi saksalaisella kielialueella syntyneen vertailevan musiikkitieteen sekä Yhdysvalloissa syntyneen modernin kulttuuriantropologian vaikutusvaltaisimmat käynnistäjät olivat olleet juutalaisia. Siis miksi juuri he olivat etualalla kehittämässä tutkimusaloja, joilla etniset ja nationalistiset kysymykset olivat vain vähäisesti merkityksellisiä ja joilla tutkijat etsivät erilaisuuksien ja samanlaisuuksien syitä ja seurauksia koko maapallon näkökulmasta? Juutalaisten 
aktiivisuus hämmentää. Kysymys on kuitenkin aiheellinen, sillä olihan 190o-luvun alun Eurooppa täynnään musiikin tutkimuksesta kiinnostuneita ajattelijoita.

Oletukseni on, että vertailevan musiikintutkimuksen johtohahmoilla ei ollut paikallisuuteen liittyneitä kansallisia intohimoja. Heidän tutkimuksensa osoittavat, että heitä kiinnosti ihminen, musiikki ja ihmisen kulttuurinen variaatio globaalista näkökulmasta. Tutkijoita ajoi eteenpäin tarve ymmärtää, mistä saman piirteen (laulutyylin ja rytmiikan tai vaikkapa mytologian, moraalin, ruokatalouden) monimuotoisuus tai yhdenmukaisuus johtuu. He tekivät empiiristä tutkimuksia, ja heille oli yhdentekevää, oliko analyysin kohteena taidemusiikki vai kansanmusiikki. Keskeisenä lähtökohtana oli tutkia ihmisen ja musiikin välistä suhdetta universaalista näkökulmasta. Koulukunnan edustajat tunsivat hyvin Carl Stumpfin teoksen musiikin alkuperästä, jossa musiikki ja kieli esittäytyvät erilaisiksi viestijärjestelmiksi. Täten heidän mieleensä ei koskaan noussut ajatus esittää tieteellisenä väittämänä, että musiikki olisi "kansainvälinen kieli". Aivan selvää edelleen on, että vaikka heillä saattoi olla vahva paikkaidentiteetti, kansallisuussidos liittyi siihen heikosti (ks. Yerushalmi 1996; ks. myös Harviainen \& Illman 2003). Tämä näyttäisi olevan syynä siihen, etteivät vertailevan musiikkitieteen edustajat tehneet tutkimuksia saksankielisen väestön kansanmusiikista, minkä seurauksena Saksassa nousi sittemmin esiin näkemys, että maan kansanmusiikki oli kadonnut toisen maailmansodan jälkeen. Tämän väitteen minulle kertoi henkilökohtaisesti Göttingenin yliopiston musiikkietnologian professori Rudolf Brandl vieraillessaan Tampereen yliopiston kansanperinteen laitoksessa vuonna 1987, jolloin hänen opiskelijansa tallensivat uudelleen löydettyjen kansanmuusikoiden perinteitä Saksassa.

\section{Armas Otto Väisänen}

Erich von Hornbostelia 13 vuotta nuorempi Armas Otto Väisänen (1890-1969) asettui opintojensa avulla Savonrannalta (Raivio 2011) Helsinkiin ja kohosi yhdeksi Euroopan kansanmusiikintutkimuksen keskeisistä toteuttajista 1900-luvun ensipuoliskolla (Laitinen 2011a). Tässä yhteydessä Väisästä on turha liiemmin esitellä, koska hänen elämäntyönsä keskeisiä aineksia on analysoitu usean kirjoittajan voimin Kalevalaseuran vuosikirjassa 2011. Tieteenhistorian jatkumossa 
Väisänen edusti samaa maantieteellis-historiallista eli "suomalaista" koulukuntaa kuin hänen arkeologian, folkloristiikan (Hautala 1954) ja etnologian kollegansa. Tuo koulukunta oli osa laajempaa eurooppalaista vertailevaa tutkimusta, jota Erich von Hornbostel edusti. Suomessa vertailu oli kuitenkin paljolti kansalliskeskeistä, kun taas saksankielinen tutkijakunta edusti globaaliajattelua (Schneider 1976; Schneider 1991: 293-317; Christensen 1991: 201-209).

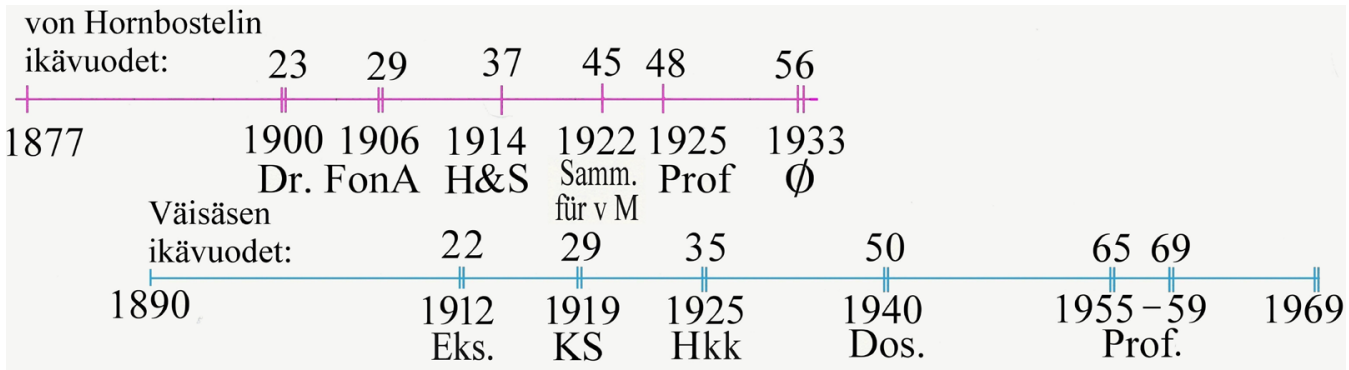

Kuva 4. Erich von Hornbostelin (yllä) ja Armas Otto Väisäsen (alla) elämän taitekohtia. Hornbostelin ura nousi ikävuosien 23 ja 48 välissä ja päättyi hieman ennen kuin 50-vuotiaan Väisäsen akateeminen ura alkoi kenttätyömatkojen (Eks.), tohtorinväitöksen ja pikaisesti saadun dosentuurin myötä. Väisäsellä Eks. = kymmenvuotisen kenttätyömatkavaiheen alku; Ks = Kalevalaseura ja Hkk = Helsingin kansankonservatorio. Ikävuodet osoittavat kummankin urakehityksen edenneen jokseenkin yhtäläisin loikin.

Jos tarkastellaan Väisäsen kansainvälisissä artikkeleissaan esittämiä päätelmiä, voidaan saada hieman valoa siihen, miten hän asemoi itsensä osana aikansa perinnetieteiden kenttää. (Tässä lueteltujen artikkeleiden taustoja on tarkkaan selvitellyt Heikki Laitinen 2011b.) Vuonna 1928 ilmestyi perusteellinen, näppäiltävää kielisoitinta koskeva artikkeli "Das zupfinstrument gusli bei den Wolgavölkern", jossa hän totesi, ettei Volgan kansojen krezillä ole yhteyttä Itämeren kanteleeseen ja että slaavien sanalla gusli on eri historia kuin sanalla kantele. Vuonna 1930 ilmestyi "Die Leier der ob-ugrischen Völker", jossa Väisänen osoitti, etteivät 
itäslaavit eivätkä germaanit tunteneet Obin ugrilaisten lyyraa, josta on kuitenkin varhaisia todisteita ajanlaskuamme edeltäneeltä ajalta. Väisänen uskalsi väittää, että pitkänomainen lyyra nares-juh oli lainattu ensimmäisellä esikristillisellä vuosituhannella vaikuttaneista kulttuurikeskuksista Kaukasuksen eteläpuolelta. Väite sopii hyvin kielitieteen ja arkeologian nykyiseen näkemykseen, jonka mukaan sana ugri palautuu kanta-arjan mahtavaa, jaloa ja pelottavaa tarkoittavaan adjektiiviin ugrá. Sana on vuosituhansien ajan esiintynyt sekä muinaisiranissa (avestassa) että muinaisarjassa jumalten ja arvostettujen miesten niminä kuten myös Intiassa mahtavien heimojen nimistössä (Pekkanen 1973; Carpelan \& Parpola 2001: 113). Obinugrilaisten esivanhemmilla oli pronssikaudella ollut suora yhteys kanta-arjaa puhuneisiin etelänaapureihinsa, joilla taas oli kaupalliset yhteydet lyyrasoitinten maille Mesopotamiaan eli nykyiseen Irakiin.

Vuonna 1937 Väisänen julkaisi artikkelin "Die obugrische harfe", jossa hän otti saman kannan kuin Curt Sachs: ugrilaisen harpun alkuperä palautuu Mesopotamiaan. Samana vuonna ilmestyi Norjassa ruotsinkielinen elämänkerta-artikkeli "Larin Paraske". Siinä kohteena oli suursuomalaisten kulttihahmo Paraskeva Nikitina, joka oli Kannaksen inkerikko eli ižori. Hänen traditionsa oli itämerensuomalainen, muttei suomalainen. Tässä Väisänen kuitenkin katsoi, että Paraskeva - samoin kuin myöhemmin paimensävelistään tunnettu soittaja Teppo Repo Länsi-Inkeristä - olivat "suomalaisia". Vuonna 1938 Tanskassa ilmestyi Väisäsen artikkeli "Wirklichkeitsgrund der finnisch-estnischen Kantelerunen", jonka ensiasu oli ilmestynyt suomeksi 1928 nimellä "Kantelerunojen todellisuuspohja". Siinä hän osoitti laulettujen runojen kuvaavan aiempaa kulttuuria melko realistisesti, ja milloin näin ei Väisäsen mielestä ollut, runojen motiivit kytkeytyivät laajalti kansainväliseen perinteeseen. Niin ikään hän puuttui siihen, että kanteleen kalamaisella profiililla on vanha yhteys itäaasialaisten eläinmuotoisiin sitroihin kuten krokotiilisitraan.

Unkarilaisen kansanmusiikin tutkijan Zoltán Kodályn juhlakirjassa ilmestyi 1943 artikkeli "A vepsze kantele", jossa Väisänen kuvaili Etelä-Vepsässä vuonna 1916 tekemänsä matkan aikana keräämiään kanteleita. Tulokset toistavat 1928 ilmestyneen gusli-artikkelin päätelmiä: Volgan gusli oli eri soitin kuin kantele. Vepsäläisten ja setujen kantele oli sointusäestyksen vuoksi siivellinen, mutta kantele sitrasoittimena oli "yhteissuomalaisen ajan perua", millä ilmauksella Väisänen viittasi aikansa käsitykseen ajanlaskun alun kantasuomalaisesta kult- 
tuurista. Sointusäestyksen hän määritti uudemmaksi perinteeksi, mutta samalla hän karttoi olettamasta soittotapaa venäläiseksi lainaksi - elettiinhän artikkelin ilmestymisen aikoihin sotatilaa. Vuonna 1943 sodanaikaisen saksalaisen propagandan käyttöön ilmestyi artikkeli "Finnische Volksmusik" lehdessä Der Norden. Sodan jälkeen 1949 Väisänen esitteli artikkelissaan "Suggestions for the methodical classification and investigation of folk tunes" asiantuntevasti Suomessa ja muualla Euroopassa luotuja menetelmiä järjestää kansansävelmien kokoelmia. 1954 ilmestyneessä artikkelissaan "Finnisch-ugrische Musik" (sarjassa Die Musik in Geschichte und Gegenwart IV) Väisänen painotti, että itämerensuomalaisista kansoista vain virolaiset ja suomalaiset olivat nousseet sivistyskansoiksi muiden pysyessä vähälukuisina ja "uhanalaisina".

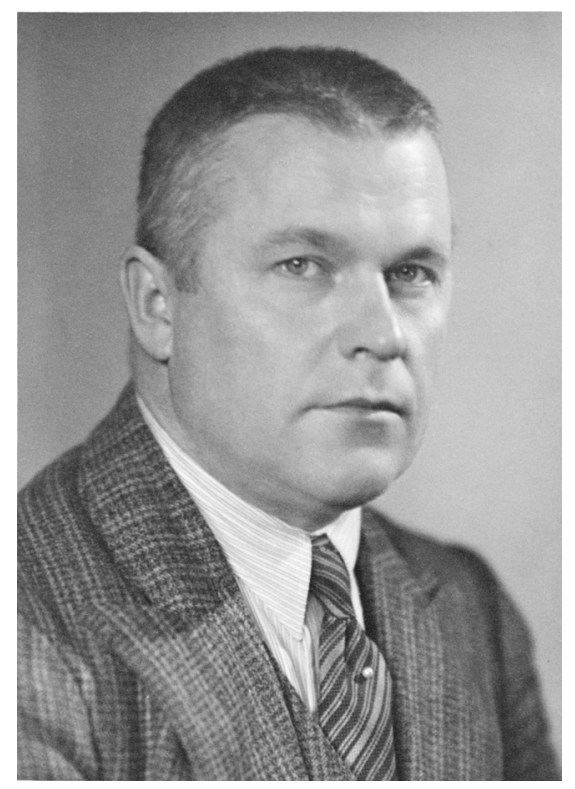

Kuva 5. A. O. Väisänen vuonna 1932. Kuva: Suomalaisen Kirjallisuuden Seuran arkisto.

Väisäsen tutkimuksista käy ilmi, että hän tukeutui päätelmissään lähtöoletukselle, jonka mukaan eri kansoja yhdistävät samankaltaisuudet johtuvat ennen kaikkea kulttuuripiirteiden lainautumisista. Nykytutkijat puhuisivat yhteisistä areaalipiirteistä. Runsas sata vuotta sitten hän oli arvellut, että kantele oli alkuaan siirtynyt germaaneilta balteille ja heiltä "meille" eli itämerensuomalaisille 
(Laitinen 2011b: 236). Tässä Väisänen toimi objektiivisen tutkijan tapaan, ja tämä ominaisuus säilyi hänessä, minkä vuoksi hän on tutkimuksineen edelleenkin ajankohtainen. Hän suunnitteli kauan väittelevänsä Itämeren alueen kanteleesta, mutta talvisodan aattona 1939 ilmestynyt väitös käsittelikin obinugrilaisten sävelmien piirteitä.

Armas Otto Väisänen toimi Helsingin kansankonservatorion rehtorina 19251957. Konservatorion olivat vuonna 1922 perustaneet Helsingin työväenopiston johtaja Zachris Castrén sekä lyseon laulunopettaja ja yliopiston musiikkitieteen dosentti Armas Launis. Rehtorin toimet veivät vuosikymmenet suuren osan Väisäsen työajasta. Hän oli vuodesta 1919 alkaen kuitenkin tiiviisti mukana Kalevalaseurassa toimimalla sen sihteerinä, toimittamalla Kalevalaseuran vuosikirjaa sen ensinumerosta talvisotaan (1921-1939) ja vaikuttamalla seuran puheenjohtajana välirauhasta vuoteen 1962. Tämä yli kolmikymmenvuotinen työrupeama oli antoisa, mutta vei runsaasti aikaa tutkimustyöltä (Kalleinen 2011; Raivio 2011). Lisäksi Väisänen oli 191o-luvulla kirjoittanut Heikki Klemetin Säveletär-lehteen ja hetken aikaa myös toimittanut sitä. Vuonna 1924 hän oli päätynyt toimittamaan alkuaan nuorsuomalaisen puolueen piirissä syntynyttä kulttuuripoliittista Valvoja-lehteä, johon oli 1923 sulautettu myös Aika-niminen lehti. Valvoja-Aikaa Väisänen toimitti 1924-1937. Musiikkitieteen professorina hän oli nelisen vuotta (1956-1959), joten hänen kautenaan tohtoriksi väitteli 1956 Helsingissä uutta aikakautta enteillyt Erkki Ala-Könni (Leisiö 1996), ja samana vuonna Väisänen hyväksyi Paavo Helistön pro gradun Eino Leinon runojen sävellyksistä.

Edellä esitellyn pohjalta nousee kysymys, miten A. O. Väisänen suhtautui kansallissosialismiin. Hänellä oli likeinen yhteys kirjailija Maila Talvioon, joka oli kesällä 1936 järjestänyt suomalaisuutta esittelevät Pohjoismaiset päivät saksalaisille vieraille Lyypekissä. Juhlissa olivat muiden muassa Eino Jutikkala, Kustaa Vilkuna sekä A. O. Väisänen kerallaan itäistä musiikkia esittäneet Oksenja Mäkiselkä, Antero Vornanen ja Teppo Repo sekä keskipohjalainen polskataituri Emil Risku. Näitä juhlia eritellyt Tomi Mertanen (2012) tuli tulokseen, että “huolimatta kytköksistään natsi-Saksaan ei Talviota voi luonnehtia kansallissosialistiksi". Tämä pätee myös Väisäseen, joka monen suomalaisen tapaan oli huolestunut Neuvostoliiton jatkuvasta uhasta ihailematta saksalaista uhoa. Tällaiseen tulkintaan antavat viitteitä sekä Mantere (2017) että Jokisipilä \& Könönen (2013). 
1930-luvulla Väisänen arvosti saksan kielellä julkaistua tutkimusta, ja vaikka hän hallitsi venäjän kielen, hän harvoin tukeutui venäläisiin kirjoittajiin. Tutkielmassaan "Selityksiä Satko-runoon" (1946) hän mietti laajan lähdeaineiston pohjalta, minkälainen tausta Novgorodin keskiaikaisella bylina-sankarirunoelmalla "guslia soittavasta Satkosta" mahtoi olla. Riippumatta venäläisestä tulkinnasta hän tuo esiin mahdollisuuden, että bylinan ydin palautuisi karjalaiseen alkuperään ja että itse tarina köyhän kauppiaan soittotaidoista ja rikastumisesta keskittyy Ilmajärven, Laatokan ja Suomenlahden seuduille. Hän tukeutuu myös slavisti J. J. Mikkolan lausuntoon, jonka mukaan nimeä Sadko ei voida johtaa slaavilaisesta nimistöstä, josta se poikkeaa siinäkin, ettei bylinassa koskaan mainita Sadkon isännimeä. Lauri Harvilahti (1985: 16-19) sen sijaan arvelee nimeä slaavilaisperäiseksi mutta ei perustele oletustaan. Tämän artikkelin kannalta oleellista on kuitenkin tajuta, että Väisänen edusti diffuusioteoriaa (MuinaisKarjalasta edennyt laina Novgorodin sloveeneille), Harvilahti taas evoluutioteoriaa (neitseellinen synty Novgorodin sloveenien keskuudessa).

\section{Päätteeksi}

Tietääkseni A. O. Väisäsen ei tutkimuksissaan koskaan viitannut Erich von Hornbosteliin. Sen sijaan hän tukeutui Carl Stumpfiin ja Curt Sachsiin. Soitintutkijana Sachs (esim. 1929 ja 1977) toki oli universalisti, mutta hänen kirjansa tanssin maailmanhistoriasta keskittyy paljolti Eurooppaan. Sachs ei ollut nuotintaja, joten hän lainasi Hornbostelin transkriptioita. Taidehistorioitsijana Sachs julkaisi loputtomasti soitinkuvia, ja Väisänen lainaili juuri Sachsin kautta kuvastoa ja Hornbostelin sävelmistöä. Miksi hän ei viitannut suoraan Hornbosteliin? Vastaus on mielestäni ilmeinen. Väiteltyään Erich von Hornbostel ei enää kirjoittanut ainuttakaan kirjaa. Hänen tuotantonsa on yksittäisinä artikkeleina mitä erilaisimmissa julkaisuissa, joita Väisäsen oli likimain mahdoton jäljittää. Sen sijaan Stumpf julkaisi musiikin alkuperää käsittelevän monografiansa ja Sachs puolestaan lukuisia monografioita, joihin Väisänen viittasi. 


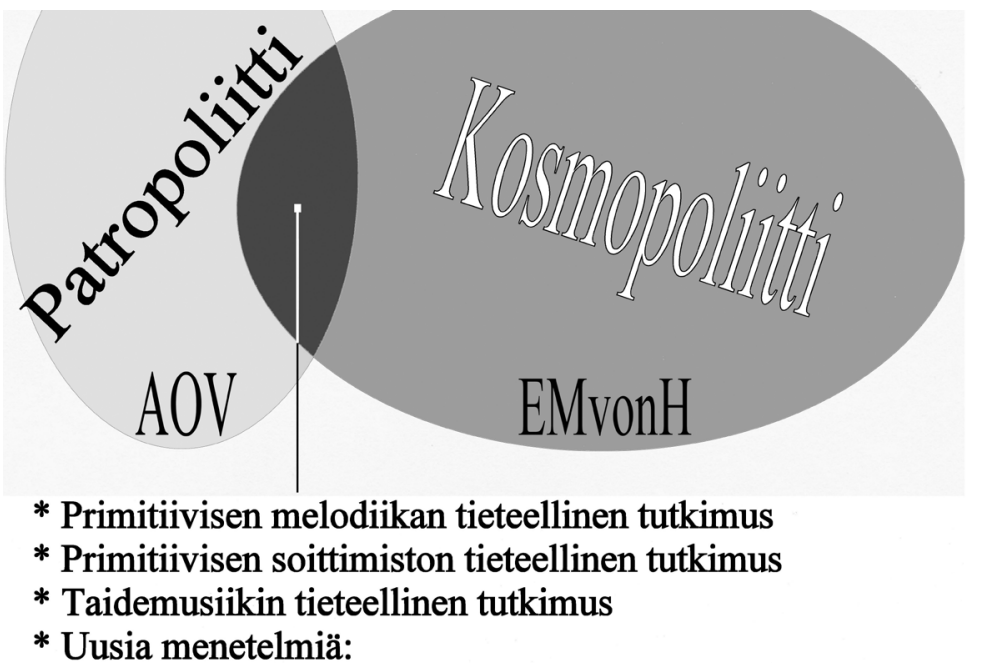
A. Fonogrammien tarkka nuotintaminen
B. Nuottien järjestäminen ja vertailu
C. Tulosten sijoittaminen paikkaan ja paikan sitominen aikaan eli (esi)historiaan
D. Sama menetelmä tarkkaan kuvatuilla soittimilla

* Musiikin evoluution mietiskely esikuvana Carl Stumpf

Kuva 6. A. O. Väisäsen ja Erich von Hornbostelin poikkeavista peruslähtökohdista (isänmaallisuus vs. universaalisuus) huolimatta he toteuttivat samankaltaisia ja tieteenalalla uusia menetelmiä sekä diffuusio-oletukseen pohjaavia päätelmiä. Sana primitiivinen tarkoittaa tässä yhteisöä, joka ei tunne kirjoitustaitoa eikä luokkajakoa.

Kuva 6 pyrkii osoittamaan, miten Väisäsen toiminta oli keskeisimmiltä osiltaan samanlaista kuin Hornbostelin. Vastaavuus johtuu siitä, että kumpikin pyrki itsenäisesti ratkaisemaan samanlaisia tutkimuksellisia ongelmia aikana, jolloin heillä ei vielä ollut valmiita toimintamalleja. Kummankin oli pakko löytää ratkaisuja itse. Tässä mielessä he olivat vapaampia kuin monet nykytutkijat, jotka etsiessään ratkaisuja arastelevat ja tukeutuvat liiaksi esikuviensa antamiin malleihin. Termi kosmopoliitti tarkoittaa maailmankansalaista, joka ei henkisesti ole sidoksissa tiettyyn kotiseutuun. Patropoliitti (pohjalla latinan patria, "kotiseutu") tarkoittaa henkilöä, jonka maailmankuva kytkeytyy johonkin laajaan mutta hypoteettiseen "kotiseutuun" kuten uralilaisten kansojen yhtenäiseen alkukotiin. Molemmat piirteet ohjailevat tutkijoiden ja poliitikkojen toimintaa, ja kumman- 
kin pohjalle saattaa kehittyä ääneen lausumaton, mutta ajattelua ohjaava lisä- eli metateoria.

Merkittävin ero Hornbostelilla ja Väisäsellä liittyi tutkimusaineiston hankintaan. Hornbostel tutki koko maapalloa nuotintamalla äänityksiä, joita hän ei pääsääntöisesti ollut itse tallentanut. Vauraassa maassa asunut Hornbostel kykeni lunastamaan Berliinin arkistoon fonogrammikokoelmia, joita virkamiehet, lähetyssaarnaajat, matkailijat ja tutkijat olivat äänittäneet eri puolilla maapalloa. Vaikka myös Väisänen nuotinsi ja julkaisi muiden äänityksiä, esimerkiksi tutkijoiden tallentamia obinugrilaisten, mordvalaisten ja samojedien sävelmiä (Väisänen 1937C; 1948; 1965), hän teki runsaasti kenttätöitä. Väisänen tutki uralilaisten kansojen aluetta nuotintamalla itse tallentamiaan äänityksiä. Hän myös julkaisi omia nuotinnoksiaan, tunnettuna esimerkkinä vuonna 1928 ilmestynyt kokoelma Kantele- ja jouhikkosävelmiä (vrt. Blomster 2011 ja Laitinen 2011b). Lisäksi Väisänen tallensi muun muassa inarinsaamelaisia joikuja ja kolttien leutteja.

Molemmat tutkijat hyödynsivät notaatiotaitojaan. Hornbostelilla oli valtava halu ymmärtää ihmisen musiikin kokonaisuutta, minkä vuoksi hän oli kiihkeä ja tarkka nuotintaja. Juuri Hornbostel saksansi Alexander Ellisin artikkelin, jossa oivalluksena oli muuntaa oktaavi 1200 sentin eli ellisin kokonaisuudeksi, ja juuri Hornbostel loi taulukot, jotka auttoivat myöhemmin tutkijoita muuntamaan intervallien taajuudet absoluuttisista hertseistä suhteellisiksi senteiksi (Kunst 1950: 8-19) ja lopulta mahdollistivat sävelkorkeuksien tarkan määrittämisen notaatioissa. Väisänen harjoitti samankaltaista luovaa teorianmuodostusta sävelmän muotoanalyysin alalla. Hän hallitsi tutkijoiden erilaiset periaatteet ryhmitellä ja järjestää sävelmäkokoelmat loogisella tavalla. Hän loi kuitenkin oman menetelmänsä, jonka avulla olisi mahdollista vertailla systemaattisesti eri väestöjen sävelmistöjä keskenään (Laitinen 2011: 250-253). Väisänen käytti sen yhtä asua väitöskirjassaan, mutta valitettavasti hän ei milloinkaan toteuttanut todellista vertailevaa tutkimusta, vaikka hänen "sanakirjallinen" menetelmänsä puri yhtä lailla samojedien ja komien kuin virolaisten ja saamelaisten sävelmistöihin.

Väisäsellä ei Suomessa ollut suuriakaan taloudellisia mahdollisuuksia hankkia ulkopuolisten tekemiä äänitteitä, ja niinpä hänen oli koottava tutkimusaineistonsa itse. Väisänen ei myöskään tukeutunut senttiarvoihin, vaan luotti kuuloonsa, mutta hänenkin transkriptionsa ovat Hornbostellin nuotinnosten tapaan luotettavia ja riittäviä etenkin melodioiden syntaksin ymmärtämiseen. Tässä yh- 
teydessä on muistettava, että myös musiikintutkija Armas Launiksen puutteellisissa olosuhteissa 1900-luvun alussa tekemät joikunuotinnokset ovat (saamelaistenkin mielestä) kielellisesti hämäriä mutta melodioina luotettavia. Täten on kysyttävä, miksi laitekeskeinen nykytutkija ei luota varhaisiin nuotintajiin, joiden kyky nuotintaa oli epäilemättä myöhäisiä epäilijöitään ammattitaitoisempi. Tosiasia toisaalta on, että epäilijöillä on perusteensa, kuten Jarkko Niemi (1994; 1995) on osoittanut analysoituaan Väisäsen samojedilaisia transkriptioita.

Edellä ilmenneen perusteella voidaan ensinnäkin todeta, että vertailevan musiikkitieteen "koulukunnat" Wienissä ja Berliinissä eivät olennaisesti eronneet toisistaan. Niitä yhdisti halu ymmärtää kulttuuripiirteiden ja ihmisten muuttoliikkeiden globaalia esihistoriaa, jota tutkijat hahmottelivat luomalla oletuksia toinen toistaan seuraavista asutusaalloista, kulttuuripiireistä. Keski-Euroopan musiikintutkijat vierastivat evolutionistisia selityksiä, alkoivat koota tietoisesti kansainvälisiä äänitekokoelmia ja arvostivat Wienin yliopistossa toimineen katolisen teologin ja orientalistin Wilhelm Schmidtin ajatuksia. Musiikki ja psykologia nousivat Wieniä keskeisemmiksi tutkimuskohteiksi Berliinissä, jossa Carl Stumpfin oppilaiksi alkoi hakeutua juutalaista älymystöä. Hitlerin onnistuttua nousemaan yksinvaltiaaksi valtakunnankanslerina ja johtajana 1933 Berliinin koulukunta kuihtui hetkessä, ja tutkijat pakenivat Saksasta kuka mitäkin kautta Yhdysvaltoihin. Stumpf jaksoi vielä kolme vuotta Hitlerin aikaa, mutta musiikintutkimuksen päämäärät sumentuivat.

Vertaileva musiikkitiede toki säilyi Euroopan eri maissa, mutta sen rinnalle sodan jälkeen Yhdysvalloissa hahmottui kulttuuriantropologian ja musiikkitieteen yhdistelmänä etnomusikologian suuntaus. Sen johtohahmoksi nousi selkeästi vertailevan musiikkitieteen synteesejä luonut Curt Sachs, joka alkoi kirjoittaa ja opettaa Yhdysvalloissa englanniksi. Etnomusikologian keskeisimpänä teoreetikkona Alan Merriam ei asettunut Sachsia vastaan. Mutta mihin siis Erich von Hornbostel katosi? Uskallan toistaiseksi vain olettaa, että Sachs omaksui statuksensa painottamatta tutkimuksiensa läheistä yhteyttä kollegansa Erich von Hornbostelin tutkimustuloksiin. Tämä on ymmärrettävissä, koska Sachsin oli pakolaisena pakko taistella asemastaan Yhdysvalloissa. Hornbostelin aseman hiipumisen toisena syynä oli se, että vain harvat osasivat Yhdysvalloissa saksaa ja kolmantena jo edellä todettu: Horbostel julkaisi ajatuksiaan artikkelein, ei kirjoina. 
Arvioni mukaan Erich von Hornbostel oli vertailevan musiikkitieteen keskeisin toimija Keski-Euroopassa. Suomessa hänen vertaisensa tutkija 19oo-luvun ensipuoliskolla oli Armas Otto Väisänen. Kummatkin olivat uutta luovia, ja molemmat keksivät päätyä samanlaisiin ratkaisuihin vailla aiempia esikuvia, malleja ja ajattelijoita, joihin olisi voinut tukeutua ja luottaa. Tässä mielessä he toteuttivat evoluutioteoriassa tunnistettua parallelismia: päätyivät toisistaan tietämättä samankaltaisiin oivalluksiin.

\section{Kirjallisuus}

Berner, Margit, Dick, Anita \& Wilfing, Harald (2015) “Wiener Anthropologien”. Reflexive Innensichten aus der Universität. Toim. Karl Anton Fröschl ym. Göttingen: V\&R unipress, 4153. https://doi.org/10.14220/9783737004152.41

Blomster, Risto (2011) “Luettelo A. O. Väisäsen äänittämistä vahalieriöistä Kansanrunousarkistossa". Taide, tiede, tulkinta. Kirjoituksia A. O. Väisäsestä. Toim. Ulla Piela, Seppo Knuuttila ja Risto Blomster. Kalevalaseuran vuosikirja 9o. Helsinki: Suomalaisen Kirjallisuuden Seura, 280-285.

Burke, David (2014) The Lawn Road Flats. Spies, Writers and Artists. Woodbridge: Boydell Press. Carpelan, Christian \& Parpola, Asko (2001) “Emergence, contacts and dispersal of Proto-IndoEuropean, Proto-Uralic and Proto-Aryan in archaeological perspective". Early Contacts between Uralic and Indo-European: Linguistic and Archaeological Considerations. SuomalaisUgrilaisen Seuran Toimituksia 242. Toim. Christian Carpelan, Asko Parpola \& Petteri Koskikallio. Helsinki: Suomalais-Ugrilainen Seura, 55-150.

Christensen, Dieter (1991) “Erich M. von Hornbostel, Carl Stumpf, and the Institutionalization of Comparative Musicology". Comparative Musicology and Anthropology of Music. Toim. Bruno Nettl \& Philip V. Bohlman. Chicago: University of Chicago Press, 201-209.

Ebeling Martin \& Langner, Gerald (2016) "Gibt es eine auditive Massnorm?" Carl Stumpfs Berliner Phonogrammarchiv. Schriftenreihe der Carl Stumpf Gesellschaft. Band 6. Toim. Martin Ebeling. Frankfurt am Main: Peter Lang, 9-23. https:/ / doi.org/10.3726/978-3-653-06400-1 Ferrington, Benjamin (1971) Mitä Darwin todella sanoi. Helsinki: wsor. Frobenius, Leo (1898) Der Ursprung der afrikanischen Kulturen. Berlin: Gebr. Borntraeger. Goodman, Simon (2015) "Susanne Hornbostel". Geni https:/ /www.geni.com/people/SusanneHornbostel/600000016830990150 (luettu 16.07.2016). 
Goodman, Simon (2016) "Helene von Hornbostel". Geni https:/ /www.geni.com/people/ Helene-von-Hornbostel/6000000016830959167 (luettu 16.07.2016).

Greenberg, Joseph C. (1971) Melville Jean Herskovits 1895-1963. Washington: National Academy of Sciences. Ks. http:/ / www.nasonline.org/publications/biographical-memoirs/memoirpdfs/herskovits-melville.pdf

Gronow, Pekka \& Saunio, Ilpo (1990) Ä̈̈nilevyn historia. Helsinki: wsor.

Gronow, Pekka \& Hofer, Christiane (toim.) (2009-2010) The Lindström Project. Contributions to the History of the Record Industry. Vol. 1-2. Wien: Gesellschaft für Historische Tonträger.

Harviainen, Tapani \& Illman, Karl-Johan (2003) Juutalainen kulttuuri. Helsinki: Otava.

Harvilahti, Lauri (1985) Bylinat. Venäläistä kertomarunoutta. Tietolipas 98. Helsinki: Suomalaisen Kirjallisuuden Seura.

Hautala, Jouko (1954) Suomalainen kansarunoudentutkimus. Suomalaisen Kirjallisuuden Seuran Toimituksia 244. Helsinki: Suomalaisen Kirjallisuuden Seura.

Hornbostel, Erich M. von (1910) “Über vergleichende akustische und musikpsychologische Untersuchungen". Beiträge zur Akustik und Musikwissenschaft Band 5, 143-167.

Hornbostel, E. v. (1913) “Über ein akustisches Kriterium für Kulturzusammenhänge”. Beiträge zur Akustik und Musikwissenschaft Band 7, 1-20.

Hornbostel, Erich M. von \& Sachs, Curt (1914) “Systematik der Musikinstrumente. Ein Versuch". Zeitschrift für Ethnologie Band 46, Heft 4-5, 553-59o. [Suomennettuna http:/ /www.uta.fi/ yky/tutkimus/etnomusikologia/projektit/soitinluokitus.pdf ]

Hornbostel, Erich M. von (1923) “Beobachtungen über ein- und zweiohriges Hören”. Zeitschrift für Psychologie und ihre Grenzwissenschaften 4, 64-149. https://doi.org/10.1007/BF00410634

Hornbostel, Erich M. von (1928) “Die Massnorm als kulturgeschichtliches Forschungsmittel”. Publication d'Hommage offerte au P. W. Schmidt. Toim. W. Koppers. Wien: MachitraristenCongretation-Buchdruckerei, 303-323.

Hornbostel, Erich M. von (1933a) “The Ethnology of African Sound-instruments I". Africa Vol. 6: 2, 129-157. https://doi.org/10.2307/1155180

Hornbostel, Erich M. von (1933b) “The Ethnology of African Sound-instruments II. Africa Vol. 6:3, 277-311. https://doi.org/10.2307/1155678

Jokisipilä, Markku \& Könönen, Janne (2013) Kolmannen valtakunnan vieraat: Suomi Hitlerin Saksan vaikutuspiirissä 1933-1944. Helsinki: Otava.

Kalleinen, Kristiina (2011) “A. O. Väisänen ja Kalevalaseura”. Taide, tiede, tulkinta. Kirjoituksia A. O. Väisäsestä. Toim. Ulla Piela, Seppo Knuuttila ja Risto Blomster. Kalevalaseuran vuosikirja 9o. Helsinki: Suomalaisen Kirjallisuuden Seura, 82-93. 
Koch, Lars-Christian, Wiedmann, Albrecht \& Ziegler, Susanne (2004) “The Berlin PhonogrammArchiv: A treasure of sound recordings". Acoustical Science and Technology 25:4, 27-231. https://doi.org/10.1250/ast.25.227

Kunst, Jaap (1948) Around von Hornbostel's Theory of the Cycle of Blown Fifths. Mededeling no. 76. Amsterdam: Koninklijke Vereeniging Indisch Instituut.

Kunst, Jaap (1950) Musicologica. A Study of the Nature of Ethno-musicology, Its Problems, Methods, and Representative Personalities. Amsterdam: Indisch Instituut.

Kurkela, Vesa (2011) "Kansallismielisyys Suomen musiikin historiankirjoituksessa”. Musiikki $1 / 2011,24-42$.

Laitinen, Heikki (2011a) “A. O. Väisäsen elämäntyö”. Taide, tiede, tulkinta. Kirjoituksia A. O. Väisäsestä. Toim. Ulla Piela, Seppo Knuuttila ja Risto Blomster. Kalevalaseuran vuosikirja 90. Helsinki: Suomalaisen Kirjallisuuden Seura, 13-59.

Laitinen, Heikki (2011b) “A. O. Väisäsen tutkijana”. Taide, tiede, tulkinta. Kirjoituksia A. O. Väisäsestä. Toim. Ulla Piela, Seppo Knuuttila ja Risto Blomster. Kalevalaseuran vuosikirja 90. Helsinki: Suomalaisen Kirjallisuuden Seura, 212-261.

Langner, Gerald (2015) The Neural Code of Pitch and Harmony. Cambridge: Cambridge University Press. https://doi.org/10.1017/св09781139050852

Leisiö, Timo (1996) “Erkki Ala-Könni 1911-1996.” Musiikki 3/1996, 343-346.

Lomax, Alan (1968) Folk Song Style and Culture. Publications No. 88. New York: American Association for the Advancement of Science.

Lomax, Alan \& Arensberg, Conrad (1977) “A Worldwide Evolutionary Classification of Cultures by Subsistence Systems". Current Anthropology 18:4, 659-708. https:/ / doi. org/10.1086/201975

Manninen, Ilmari (1934) “Johdanto". Suomen suku III. Helsinki: Otava.

Mantere, Markus (2017) “Ilmari Krohn, Otto Andersson, Armas Otto Väisänen ja tieteen suuri tehtävä. Suomalaisen musiikintutkimuksen suhteet Saksaan 1930- ja 1940-luvuilla". Musiikki $1-2 / 2017,86-112$.

Merriam, Alan P. (1968 [1964]) The Anthropology of Music. Second Printing. Evanston: Northwestern University Press.

Mertanen, Tomi (2012) "Maila Talvio ja suomalainen maalaisateria Lyypekissä". Tieteessä tapahtuu 30:6, 25-32.

Niemi, Jarkko (1994) “Kai Donnerin tallentamat selkuppi- ja kamassisamojedilaulut A. O. Väisäsen Samojedische Melodien -nuotinnosjulkaisussa". Etnomusikologian vuosikirja Vol. 6, 103-134. 
Niemi, Jarkko (1995) “Transcriptions of Nenets songs in A. O. Väisänen's Samojedische Melodien re-evaluated". Suomalais-Ugrilaisen Seuran Aikakauskirja 86, 147-161.

Niiranen, Timo (1987) Axel Olai Heikel : suomalais-ugrilaisen kansatieteen ja arkeologian tutkija. Kuopio: Snellman-instituutti.

Nyqvist, Niklas (2007) Från bondson till folkmusikikon: Otto Andersson och formandet av "finlandssvensk folkmusik". Åbo: Åbo Akademi University Press.

Parks, Douglas R. 1997. "Introduction". Johdanto teokseen George A. Dorsey: The Pawnee Mythology (alk. 1906). Lincoln \& London: The Bison Books Edition.

Pekkanen, Tuomo (1973) “On the oldest relationship between Hungarians and Sarmatians: From Spali to Asphali". Ural-altaische Jahrbücher 45, 1-64.

Pekkilä, Erkki (1982) “Suomalainen etnomusikologia: katsausta historiaan, tutkimusmenetelmiin ja -näkökulmiin". Musiikkikulttuurin murros teollistumisajan Suomessa. Toim. Vesa Kurkela \& Riitta Valkeila. Musiikkitieteen laitoksen julkaisusarja A:1. Jyväskylä: Jyväskylän yliopisto.

Pekkilä, Erkki (1988) Musiikki tekstinä: kuulonvaraisen musiikkikulttuurin analyysiteoria ja -metodi.

Acta Musicologica Fennica 17. Helsinki: Suomen Musiikkitieteellinen Seura.

Piela, Ulla, Knuuttila, Seppo \& Blomster, Risto (toim.) (2011) Taide, tiede, tulkinta. Kirjoituksia A. O. Väisäsestä. Kalevalaseuran vuosikirja 9o. Helsinki: Suomalaisen Kirjallisuuden Seura.

Raivio, Kaari (2011) “Isäni A. O. Väisäsen päiväkirjan kertomaa sekä perhe-elämää Mainiemessä”. Taide, tiede, tulkinta. Kirjoituksia A. O. Väisäsestä. Toim. Ulla Piela, Seppo Knuuttila ja Risto Blomster. Kalevalaseuran vuosikirja 9o. Helsinki: Suomalaisen Kirjallisuuden Seura, 6o-81.

Reed, Daniel (1993) "The Innovator and the Primitives: Georg Herzog in Historical Perspective". Folklore Forum Vol. 26:1/2, 69-92.

Sachs, Curt (1929) Geist und Werden der Musikinstrumente. Berlin: D. Reimer.

Sachs, Curt (1977 [1940]) The History of Musical Instruments. London: J.M. Dent \& Sons. Salonen, Armas (1945) Kaksoivirranmaa. Porvoo \& Helsinki: wsor.

Schneider, Albrecht (1976) Musikwissenschaft und Kulturkreislehre. Zur Methodik und Geschichte der Vergleichenden Musikwissenschaft. Bonn: Verlag für Systematische Musikwissenschaft.

Schneider, Albrecht (1991) "Psychological Theory and Comparative Musicology". Comparative Musicology and Anthropology of Music. Toim. Bruno Nettl \& Philip V. Bohlman. Chicago: University of Chicago Press, 293-317.

Schwörer-Kohl, Gretel (2016) "Auditive Massnormen in China - Vom chinesischen Kammerton Huang Zhong zum europäischen Urmeter". Carl Stumpfs Berliner Phonogrammarchiv. Schriftenreihe der Carl Stumpf Gesellschaft. Band 6. Toim. Martin Ebeling. Frankfurt am Main: Peter Lang, 25-32. 
Simon, Artur (2000) Das Berliner Phonogramm-Archiv 1900-2000: Sammlung der traditionellen Musik der Welt. Berlin: Verlag für Wissenschaft und Bildung.

Smith, Woodruff D. (1980) "Friedrich Ratzel and the Origins of Lebensraum". German Studies Review 3:1, 51-68. https:// doi.org/10.2307/1429483

Stock, Jonathan P. J. (2007) "Alexander J. Ellis and his Place in the History of Ethnomusicology". Ethnomusicology 51:2, 306-325.

Stumpf, Carl (1892) Psychologie und Erkenntnistheorie. Abhandlungen der PhilosophischPhilologischen Classe der könichlich Bayerischen Akademie der Wissenschaften.

Band 19. München: Verlag der K. Akademie. Ks. https:/ /archive.org/ stream/PsychologieUndErkenntnistheorie/Carl_Stumpf_Psychologie_und_ Erkenntnistheorie\#page/n3/mode/2up

Stumpf, Carl (1911a) Die Anfänge der Musik. Leipzig: Verlag von Johann Ambrosius Barth. Stumpf 1911b. Konsonanz und Konkordanz. Nebst Bemerkungen über Wohlklang und Wohlgefälligkeit musikalischer Zusammenklänge. Beiträge zur Akustik und Musikwissenschaft Band 6, 116-150. Ks. http:/ /echo.mpiwg-berlin.mpg.de/ECHOdocuView?url=/permanent/ vlp/lit38499/index.meta

Stumpf, C. \& Hornbostel, E. v. (1911) “Über die Bedeutung ethnologischer Untersuchungen für die Psychologie und Ästhetik der Tonkunst". Beiträge zur Akustik und Musikwissenschaft Band 6: $102-115$.

Wachsmann, Klaus P., Christensen, Dieter \& Reinecke, Hans-Peter (toim.) (1975) Hornbostel Opera Omnia. Volume I. Hague: Martinus Nijhoff.

Waterman, Christoffer A. (1990) Jùjú. A Social History and Ethnography of an African Popular Music. Chicago: University of Chicago Press. https:/ / doi.org/10.1007/978-94-010-1676-6

Vilkuna, Kustaa (1961) “Onko erityistä suomalaisugrilaista kansatiedettä?” Kalevalaseuran vuosikirja 41, 47-56. Porvoo: wsor.

Väisänen A. O. (1928a) “Das zupfinstrument gusli bei den Wolgavölkern”. Juhlakirja Yrjö Wichmannin kuusikymmenvuotispäiväksi. Suomalais-Ugrilaisen Seuran Toimituksia LvIII. Helsinki: Suomalais-Ugrilainen Seura, 303-330.

Väisänen, A. O. (1930) “Die Leier der ob-ugrischen Völker. Ihr Bau, Gebrauch und Ursprung”. Eurasia septentrionalis antiqua Vol 6, 15-29.

Väisänen, A. O. (1937a) "Die obugrische harfe". Finnisch-Ugrische Forschungen Zeitschrift xxIv.

Toim. Y. H. Toivonen ym. Helsinki: Finnisch-Ugrische Forschungen, 127-153.

Väisänen, A. O. (1937b) “Larin Paraske”. Nordens Kalender, 199-208. 
Väisänen, A. O. (1937c) Wogulische und ostjakische Melodien. Suomalais-Ugrilaisen Seuran Toimituksia Lxxıı. Helsinki: Suomalais-Ugrilainen Seura.

Väisänen, A. O. (1938a) “Wirklichkeitsgrund der finnisch-estnischen Kantelerunen". Acta Ethnologica 1, 31-57.

Väisänen, A. O. (1939) Untersuchungen über die Ob-Ugrischen Melodien. Suomalais-Ugrilaisen Seuran Toimituksia Lxxx. Helsinki: Suomalais-Ugrilainen Seura.

Väisänen, A. O. (1943a) “A vepsze kantele". Emlékkönyv Kodály Zoltán 6o. Születésnapjára. Toim. Gunda Béla. Budapest: Magyar Néprajzi Társaság, 337-342.

Väisänen, A. O. (1943b) “Finnische Volksmusik". Der Norden xx, 196-201.

Väisänen, A. O. (1946) “Selityksiä Satko-runoon". Kalevalaseuran vuosikirja 25-26. Porvoo: wsoy, 294-301.

Väisänen A.O. (1948) Mordwinische Melodien. Suomalais-Ugrilaisen Seuran Toimituksia XCII. Helsinki: Suomalais-Ugrilainen Seura.

Väisänen A. O. (1949) "Suggestions for the methodical classification and investigation of folk tunes". Journal of the International Folk Music Council I, 34-35. https:/ / doi. org/10.2307/835929

Väisänen, A. O. (1954) "Finnisch-ugrische Musik". Die Musik in Geschichte und Gegenwart IV. Kassel und Basel: Bärereiter Verlag, 229-236.

Väisänen, A. O. (1965) Samojedische Melodien. Suomalais-Ugrilaisen Seuran Toimituksia 136. Helsinki: Suomalais-Ugrilainen Seura.

Yerushalmi, Yosef Hayim (1996) Zachor: Erinnere Dich! Jüdische Geschichte und jüdisches Gedächtnis. Berlin: Verlag Klaus Wagenbach.

Ziegler, Susanne (n.d.) "Erich Moritz von Hornbostel". Recording Pioneers http:/ /www. recordingpioneers.com/RP_HORNBOSTEL1.html (luettu 16.7.2016).

ÖвL (1959) Österreichisches Biographisches Lexikon 1815-1950. Band 2, Lieferung 10, "Hornbostel, Erich von", "Hornbostel, Theodor Friedrich von". Wien: Österreichischen Akademie der Wissenschaften. 